\title{
PERANAN EKOLOGIS SHIPWRECK ATAU EXPOSED SHIPWRECK SEBAGAI MEDIA HIDUP KARANG DI PULAU BAWEAN DALAM UPAYA PERLINDUNGAN, PENGEMBANGAN DAN PEMANFAATAN SHIPWRECK ATAU EXPOSED SHIPWRECK
}

\author{
ECOLOGICAL ROLES OF SHIPWRECK OR EXPOSED \\ SHIPWRECK AS CORAL LIVING MEDIA AT BAWEAN \\ ISLAND, IN TERMS OF THEIR CONSERVATION, \\ DEVELOPMENT AND UTILIZATION
}

\author{
Heny Budi Setyorini ${ }^{1}$, Heri Priswanto ${ }^{2}$ dan Ahmad Surya Ramadhan ${ }^{3}$ \\ ${ }^{1}$ Dosen Program Studi Teknik Kelautan, Institut Teknologi Yogyakarta \\ ${ }^{2}$ Staf Balai Arkeologi Daerah Istimewa Yogyakarta \\ ${ }^{3}$ Mahasiswa Program Master of Maritime and Coastal Archaeology, \\ Universitas Aix Marseille \\ henybudi.s@gmail.com
}

\begin{abstract}
Metal salvage and theft activities have eliminated most shipwrecks at Nusa Island, and exposed shipwrecks in Gosong Gili, Bawean Island. In order to give recommendations for its conservation efforts, this study aims to identify the remaining shipwrecks or exposed shipwrecks at Nusa Island and Gosong Gili, and the types of corals and fishes in it. This study aims to prove that shipwrecks or exposed shipwrecks is not only having historical and economical value, but also ecological value for the survival of coral reef ecosystem. This is a descriptive-explorative research, data were gathered by underwater survey using GPS Map Sounder, and SCUBA diving. Shipwrecks at Nusa Island is only $30 \%$ left in fragmented form of mast, machine, boiler, propeller, ivory vessel, and bricks in the bow area. While the exposed shipwrecks at Gosong Gili is only $20 \%$ left in fragmented form boilers, machine, and ivory vessel that might be a cultural heritage according to the UU RI Number 11 of 2010 on Cultural Heritage. At Nusa Island, the corals are consisted of Poritidae and Acroporidae families, and various species reef fishes. While at Gosong Gili, there are more coral families including Merulinidae, Poritidae and Acroporidae, but their reef fishes species are fewer than Nusa island.
\end{abstract}

Keyword: Shipwrecks, Exposed Shipwrecks, Corals, Nusa Island, Gosong Gili, Bawean Island

ABSTRAK

Aktivitas perburuan dan pencurian besi tua telah mengakibatkan hilangnya sebagian besar shipwreck di perairan Pulau Nusa dan exposed shipwreck di Gosong Gili, Pulau Bawean. Penelitian ini bertujuan untuk mengetahui bagian shipwreck atau exposed shipwreck yang masih tersisa di perairan Pulau Nusa dan Gosong Gili serta berbagai jenis karang dan ikan yang hidup di shipwreck atau exposed shipwreck, sehingga dapat menjadi rekomendasi bagi upaya pelestariannya. Penelitian ini juga bertujuan untuk membuktikan shipwreck atau exposed shipwreck tidak hanya memiliki nilai historis dan ekonomis, tetapi juga nilai ekologis terutama bagi kelangsungan ekosistem terumbu karang. Penelitian ini merupakan penelitian deskriptif-eksploratif. Teknik pengumpulan data yang digunakan dalam penelitian ini adalah survei bawah air menggunakan GPS Map Sounder dan melakukan penyelaman menggunakan peralatan selam SCUBA untuk merekam temuan materi shipwreck atau exposed shipwreck dan berbagai jenis karang dan ikan disekitar shipwreck atau exposed shipwreck. Kondisi shipwreck di Pulau Nusa hanya bersisa $30 \%$ berupa fragmen tiang

Peranan Ekologis Shipwreck atau Exposed Shipwreck Sebagai Media Hidup Karang di Pulau Bawean dalam Upaya Perlindungan, Pengembangan dan Pemanfaatan Shipwreck atau Fxposed Shipwreck

(Heny Budi Setyorini, Heri Priswanto, Ahmad Surya Ramadhan) 
kapal, fragmen mesin kapal, komponen boiler kapal, fragmen baling-baling (propeller), fragmen gading-gading dan temuan bata di area haluan, sedangkan exposed shipwreck di Gosong Gili hanya bersisa $20 \%$ berupa fragmen boiler, komponen mesin dan fragmen gading-gading kapal yang berpotensi sebagai cagar budaya menurut Undang-Undang Nomor 11 Tahun 2010 tentang Cagar Budaya. Beberapa jenis karang yang terdapat disekitar shipwreck Pulau Nusa terdiri dari famili Poritidae dan Acroporidae dan ditemukan berbagai jenis ikan hias karang dan ikan konsumsi, sedangkan jenis karang yang terdapat di exposed shipwreck Gosong Gili terdiri dari famili Merulinidae, Poritidae dan Acroporidae dan ditemukan berbagai jenis ikan hias karang yang lebih sedikit dibanding Pulau Nusa.

Kata Kunci: Shipwreck, Exposed Shipwreck, Karang, Pulau Nusa, Gosong Gili, Bawean

Tanggal Masuk : 17 Januari 2018

Tanggal Diterima : 24 Agustus 2018 


\section{PENDAHULUAN}

Pulau Bawean memiliki letak strategis di perairan Laut Jawa karena berada diantara Pulau Jawa dan Pulau Kalimantan. Kondisi ini mendukung Pulau Bawean sebagai lokasi transit, jalur perdagangan kuno dan jalur pelayaran sejak masa lampau hingga sekarang, yang diperkuat oleh gambar Harmar (2010: G258:6/16) tentang keberadaan pelabuhan dan bangunan pemecah ombak yang dibangun pada masa kolonial sekitar tahun 1780 di depan pesanggrahan dan gambar Siberg (2015: 1620-1) tentang keberadaan Gudang Militer VOC di Pelabuhan Sangkapura pada tahun 1851.

Tulisan (Cribb dan Ford, 2009: 4), juga menyebutkan Pulau Bawean sebagai jantung di perairan Laut Jawa pada era kolonial. Beberapa peristiwa kapal tenggelam di Pulau Bawean seperti kapal Belanda De Ruyter, Java dan Kortanaer pada tanggal 27 Februari 1942 akibat torpedo yang disampaikan oleh Commodore Commanding China Force (1948: 3937); Denlay (2010: 3); Priswanto (2015: 2), serta kapal SS Bengal pada tanggal 2 Maret 1885, kapal Janbi Maru, Langkoeas dan Leeds City yang disampaikan oleh Hocking (1969) dan Priswanto (2016: 75), juga turut menjadi bukti keramaian jalur pelayaran di Pulau Putri tersebut. Penyebutan Pulau Bawean sebagai Pulau Putri berkaitan dengan keputusan sebagian besar laki-laki untuk pergi merantau ke Pulau Jawa, Malaysia dan Singapura yang telah berlangsung sejak awal abad XIX kemudian tinggal menetap dan melahirkan keturunan di wilayah perantauan tersebut hingga saat ini (Abdullah, 2006: 288; dan Salazar, 2016: 26).

Aktivitas perburuan dan pencurian besi tua di perairan Pulau
Bawean telah mengakibatkan hilangnya sebagian besar bangkai kapal karam terutama bila berada pada kedalaman perairan kurang dari 30 meter termasuk bangkai kapal karam yang berada di perairan Pulau Nusa dan Gosong Gili. Hal ini dibuktikan dengan hasil penelitian Priswanto (2015); Priswanto (2016); dan Taufiq (2017), bahwa shipwreck atau exposed shipwreck di perairan Pulau Nusa dan Gosong Gili hanya tersisa kurang dari $50 \%$.

Aktivitas perburuan dan pencurian tersebut tidak hanya berdampak pada hilangnya informasi dan data deskripsi kapal, tujuan pelayaran kapal dan muatan kapal, tetapi juga berdampak pada hubungan bilateral antara Indonesia dengan Belanda. Sebagaimana tulisan Edy (2016: 1-2), yang menyatakan bahwa Pemerintah Belanda mengajukan protes ke Pemerintah Indonesia akibat hilangnya tiga bangkai kapal Belanda, yaitu De Ruyter, Java dan Kortanaer pada saat menjelang peringatan 75 tahun peristiwa tenggelamnya kapal-kapal tersebut.

Hilangnya bangkai kapal juga berdampak secara ekologi berupa berkurangnya media hidup berbagai jenis karang dan keragaman ikan yang menghuni shipwreck atau exposed shipwreck di perairan Pulau Bawean. Beberapa penelitian seperti yang dilakukan oleh Oakley (1988), Work, Aeby, dan Maragos (2008), dan Hadi, Hartati dan Widianingsih (2011), telah membuktikan peranan kapal karam sebagai salah satu media yang mendukung kelangsungan hidup ekosistem terumbu karang melalui keberadaan berbagai jenis biota laut disekitar kapal tersebut.

Secara berkelanjutan, peranan histori dan ekologi dari kapal karam ini juga dapat memberikan

Peranan Ekologis Shipwreck atau Exposed Shipwreck Sebagai Media Hidup

Karang di Pulau Bawean dalam Upaya Perlindungan, Pengembangan dan Pemanfaatan

Shipwreck atau Fxposed Shipwreck

(Heny Budi Setyorini, Heri Priswanto, Ahmad Surya Ramadhan) 
peluang sebagai lokasi penanaman terumbu karang buatan, pengembangan ekowisata bahari maupun penetapan kawasan konservasi maritim. Beberapa tulisan (Müller dan Pickell, 1999; Dillenia dan Kusuma, 2009: 426 dan Ardiwidjaja, 2017: 140), telah membuktikan bahwa Indonesia memiliki sumberdaya arkeologi bawah air yang telah dimanfaatkan menjadi lokasi penyelaman terkenal antara lain: Liberty Wreck, Manado Wreck dan Karimunjawa Wreck. Selain itu, (Keputusan Menteri Kelautan dan Perikanan, 2018) juga telah menetapkan Kawasan Konservasi Maritim HMAS Perth di Perairan Provinsi Banten sebagai upaya perlindungan, pelestarian dan pemanfaatan potensi situs kerangka kapal HMAS yang tenggelam dalam peristiwa The Battle of Sunda Strait pada Februari 1942.

Berkaitan dengan uraian tersebut, maka diperlukan adanya kajian tentang peranan ekologis shipwreck atau exposed shipwreck sebagai media hidup karang di Pulau Bawean. Kajian ini sebagai langkah awal yang bertujuan untuk mengetahui bagian shipwreck atau exposed shipwreck yang masih tersisa di perairan Pulau Nusa dan Gosong Gili serta berbagai jenis karang dan ikan yang hidup di bagian shipwreck atau exposed shipwreck tersebut, sehingga dapat menjadi rekomendasi bagi upaya pelestarian shipwreck atau exposed shipwreck maupun keanekaragaman berbagai jenis karang melalui penetapan lokasi penanaman terumbu karang buatan dan apabila memungkinkan ditetapkan menjadi kawasan konservasi maritim. Kajian ini juga dapat membuktikan bahwa shipwreck atau exposed shipwreck tidak hanya memiliki nilai historis dan nilai ekonomis, tetapi juga nilai ekologis terutama bagi kelangsungan ekosistem terumbu karang di Pulau Bawean yang selanjutnya dapat memberikan peluang bagi pengembangan ekowisata bahari.

\section{METODE}

\section{Lokasi dan Waktu Penelitian}

Penelitian ini dilakukan pada tanggal 4-11 Mei 2017 di Pulau Nusa dan Gosong Gili, Pulau Bawean, Kabupaten Gresik, Provinsi Jawa Timur. Kegiatan ini merupakan rangkaian penelitian Identifikasi Potensi Arkeologi Maritim di Pulau Bawean: Bentuk dan Karakternya yang dilakukan oleh Balai Arkeologi Daerah Istimewa Yogyakarta pada tahun 2017.

Pulau Nusa berada di Desa Dedawang dan Gosong Gili berada di Desa Sidogedongbatu, sebelah tenggara Pulau Bawean (Gambar 1). Berdasarkan catatan Dictionary of Disaster at The Sea during Age of The Steam oleh (Hocking, 1969) dan hasil penelitian (Priswanto, 2016), diduga exposed shipwreck di Gosong Gili adalah SS Bengal yang tenggelam pada Maret 1885, sedangkan shipwreck di Pulau Nusa masih dalam proses identifikasi. Perbedaan istilah shipwreck dan exposed shipwreck terletak pada lokasi penemuan wreck tersebut, dimana exposed 
shipwreck adalah wreck yang masih nampak di permukaan baik pada saat pasang maupun surut, sedangkan shipwreck adalah wreck yang tenggelam di kedalaman perairan tertentu.

Hasil penelitian (Priswanto, 2016: 57), menyatakan materi shipwreck di Pulau Nusa yang masih tersisa meliputi blok mesin bagian bawah dengan poros engkol (crankshaft atau Kruk As) dan roda penggerak mesin (fly whee), sebuah baling-baling mengungkapkan materi exposed shipwreck di Gosong Gili meliputi boiler 3 buah, roda penggerak mesin, gading-gading kapal dan tiang berbentuk silinder yang ditemukan di kedalaman 2-5 meter dengan dimensi kapal berukuran panjang \pm 80 meter dan lebar 13 meter. Selanjutnya hasil penelitian (Priswanto, 2016: 51), juga mengungkapkan bahwa materi di exposed shipwreck tersebut berupa fragmen besi, paku logam, fragmen keramik

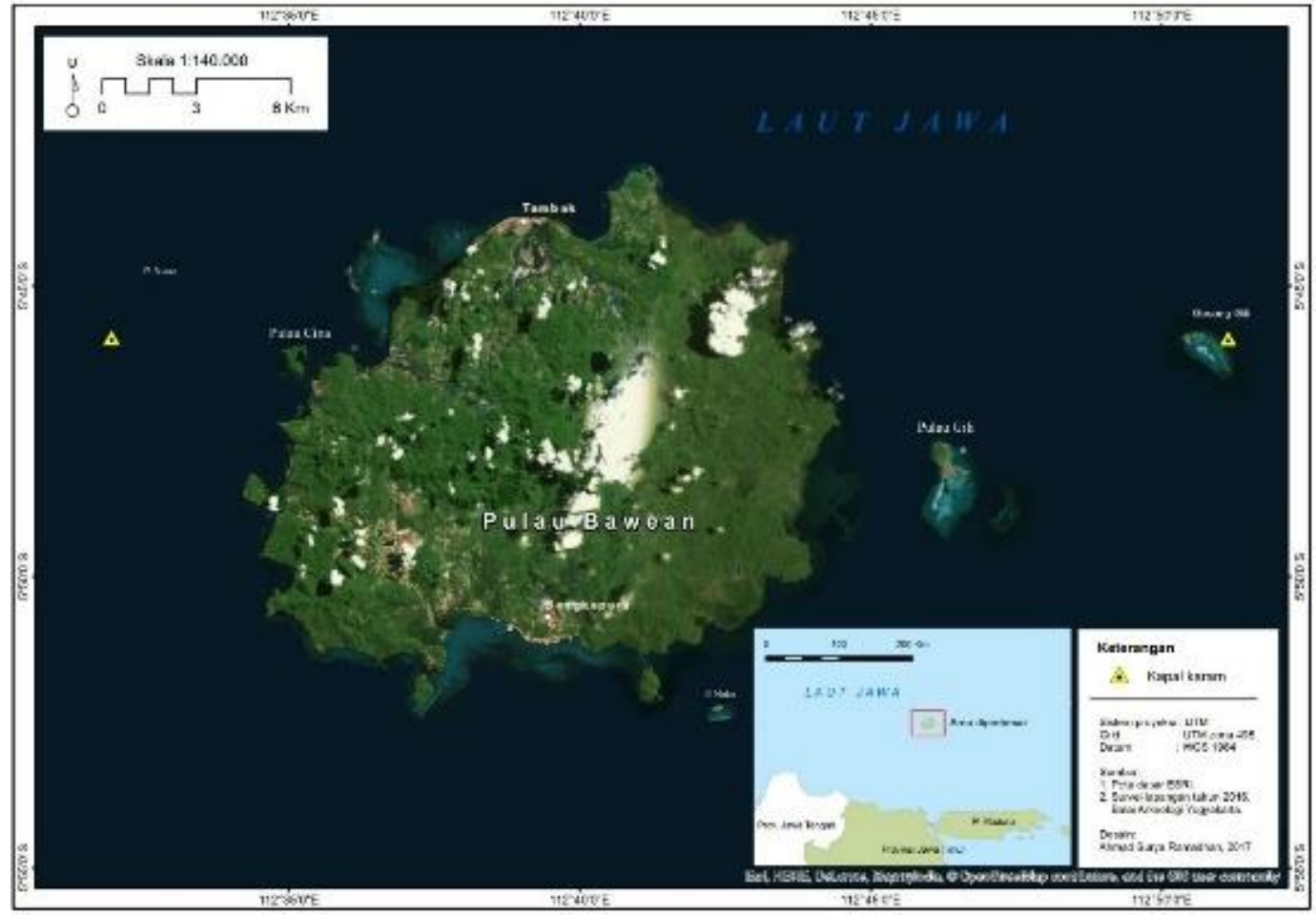

Gambar 1. Lokasi Penelitian

(Sumber: Hasil Analisis Ahmad Surya Ramadhan (2017))

(blade propeller), as gardan baling-baling, gading-gading kapal, pipa-pipa, 2 buah boiler, dan beberapa bagian kapal yang belum teridentifikasi, dimana seluruh materi tersebut ditemukan pada kedalaman 7 meter. Begitu pula dengan hasil penelitian (Priswanto, 2015: 41), yang asing bagian tepian, fragmen kayu dengan dugaan kapal tersebut merupakan jenis kapal uap.

Temuan seluruh materi shipwreck di Pulau Nusa dan exposed shipwreck di Gosong Gili diduga sebagai cagar budaya dengan mengacu pada UndangUndang Nomor 11 Tahun 2010 
tentang Cagar Budaya, sehingga perlu upaya perlindungan dari ancaman kerusakan (Priswanto, 2016: 51). Secara ekologi, materi yang tersisa dari shipwreck di Pulau Nusa dan exposed shipwreck di Gosong Gili saat ini juga telah ditumbuhi berbagai jenis karang sehingga perlu dikaji lebih lanjut mengenai jenis-jenis karang dan ikan di sekitar shipwreck atau exposed shipwreck tersebut.

\section{Sifat Penelitian}

Penelitian ini merupakan penelitian deskriptif-eksploratif yang dimaksudkan untuk memberikan gambaran seluas-luasnya tentang temuan materi shipwreck di Pulau Nusa dan exposed shipwreck di Gosong Gili serta berbagai jenis karang dan ikan disekitar shipwreck atau exposed shipwreck tersebut.

\section{Teknik Pengumpulan Data}

Teknik pengumpulan data yang digunakan dalam penelitian ini adalah survei bawah air dengan menggunakan GPS Map Sounder dan melakukan penyelaman menggunakan peralatan selam SCUBA (self contained underwater breathing apparatus) untuk merekam temuan materi shipwreck atau exposed shipwreck dan berbagai jenis karang dan ikan disekitar shipwreck atau exposed shipwreck tersebut. Hal ini berkaitan dengan posisi shipwreck di Pulau Nusa yang tenggelam pada kedalaman 5-7 meter, dimana kondisi seluruh bagian kapal berada di bawah permukaan air, sedangkan exposed shipwreck di Gosong Gili berada pada kedalaman 3-5 meter, dimana kondisi sepertiga bagian mesin terekspose ke permukaan air.
Pengamatan shipwreck atau exposed shipwreck tersebut dilakukan dengan pengukuran dan penggambaran detail pada seluruh bagian yang tersisa. Pengukuran kapal menggunakan teknik datum framework untuk shipwreck di Pulau Nusa dan baseline untuk exposed shipwreck di Gosong Gili. Selain itu, dilakukan pula perekaman data dengan dokumentasi foto dan video untuk memudahkan saat proses analisis dan intepretasi. Pengamatan dan perekaman data berbagai jenis karang dan ikan disekitar shipwreck atau exposed shipwreck dilakukan bersamaan pada saat pengamatan kedua shipwreck atau exposed shipwreck tersebut.

\section{Metode Analisis Data}

secara Analisis data dilakukan mengidentifikasi bagian shipwreck atau exposed shipwreck yang tersisa, berbagai jenis karang dan ikan disekitar shipwreck atau exposed shipwreck yang dilengkapi dengan studi literatur. Identifikasi bagian shipwreck atau exposed shipwreck yang tersisa juga dilengkapi dengan hasil penelitian Priswanto (2015); Priswanto (2016) dan Taufiq (2017). Selanjutnya, identifikasi berbagai jenis karang mengacu pada deskripsi jenis-jenis karang di Indonesia menurut Suharsono (2008), sedangkan untuk jenis ikan yang berada disekitar shipwreck atau exposed shipwreck mengacu pada identifikasi ikan karang di perairan tropis Pasifik menurut Allen, Steene, Humann, \& DeLoach (2005).

\section{HASIL PENELITIAN}

\section{Kondisi Shipwreck dan Jenis Karang di Pulau Nusa Shipwreck di Pulau Nusa berada di kedalaman 5-7 meter pada}


saat pengamatan bersandar diantara gosong karang. Berdasarkan hasil observasi dan hasil penelitian Priswanto (2016: 53) dan Taufiq (2017: 62), shipwreck tersebut berjenis kapal uap dengan sebaran komponen dan fragmen seluas $95 \mathrm{x}$ 26 meter dengan orientasi haluan kapal menghadap ke arah selatan. Kondisi shipwreck hanya bersisa $30 \%$ berupa fragmen tiang kapal, fragmen mesin kapal, komponen boiler kapal, fragmen baling-baling (propeller), fragmen gading-gading dan temuan bata di area haluan (Gambar 2-7). Hasil penelitian Priswanto (2016), juga menyampaikan bahwa sebenarnya shipwreck di Pulau Nusa telah terpetakan dalam Ducth Colonial Maps tahun 1911 di Leiden University akan tetapi belum dapat teridentifikasi akibat observasi bawah

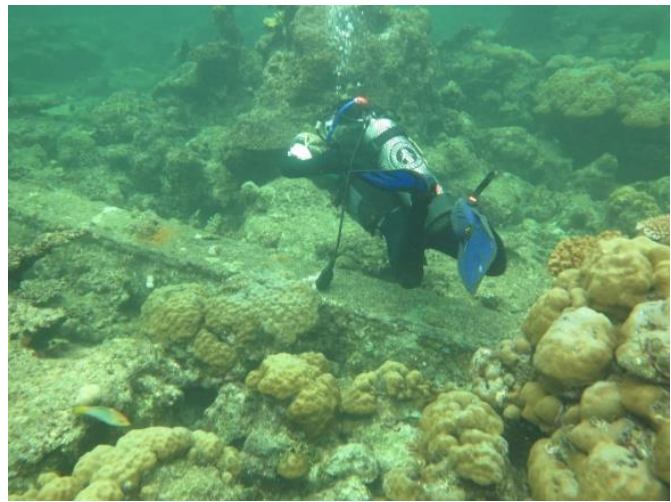

Gambar 2. Fragmen Tiang Kapal

(Sumber: Balai Arkeologi Yogyakarta, 2017)

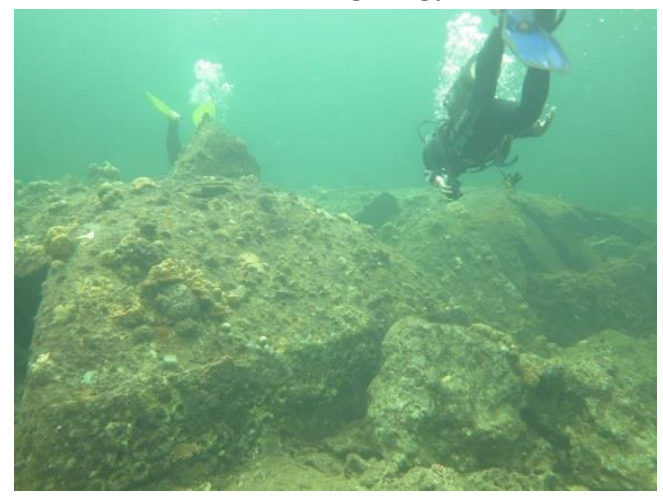

Gambar 4. Komponen Boiler Kapal (Sumber: Balai Arkeologi Yogyakarta, 2017) laut baru dilakukan pada tahapan penelitian tahun 2016.

Hasil observasi juga menunjukkan bahwa sebagian besar fragmen dan komponen shipwreck telah ditumbuhi oleh berbagai jenis karang massive maupun branching yang didukung dengan material sedimen dasar perairan berupa pasir, gravel dan pecahan karang yang berfungsi sebagai media hidup karang. Selain itu, keberhasilan berbagai jenis karang juga didukung pula dengan tingkat kejernihan perairan yang mencapai lebih dari 7 meter.

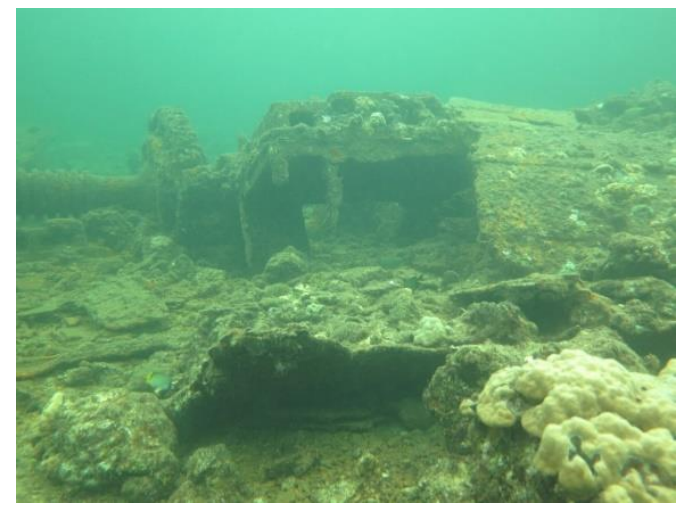

Gambar 3. Fragmen Mesin Kapal

(Sumber: Balai Arkeologi Yogyakarta, 2017)

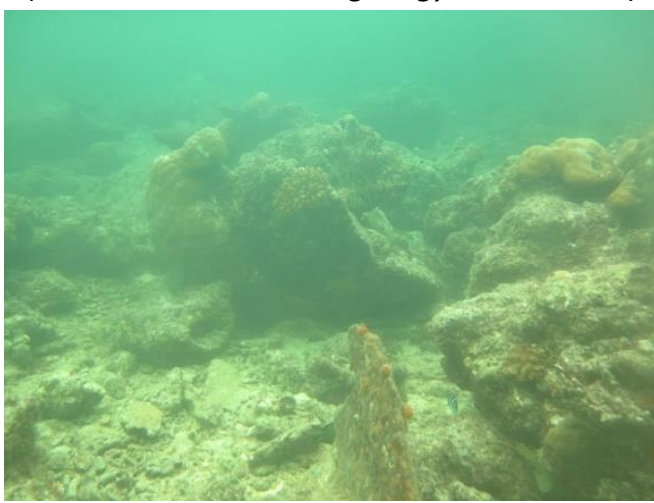

Gambar 5. Fragmen baling-baling (Propeller) (Sumber: Balai Arkeologi Yogyakarta, 2017)

Peranan Ekologis Shipwreck atau Exposed Shipwreck Sebagai Media Hidup

Karang di Pulau Bawean dalam Upaya Perlindungan, Pengembangan dan Pemanfaatan Shipwreck atau Fxposed Shipwreck

(Heny Budi Setyorini, Heri Priswanto, Ahmad Surya Ramadhan) 


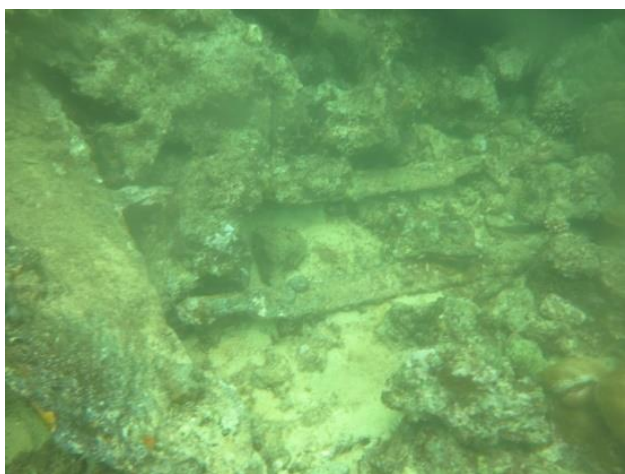

Gambar 6. Fragmen Gading-Gading (Sumber: Balai Arkeologi Yogyakarta, 2017)

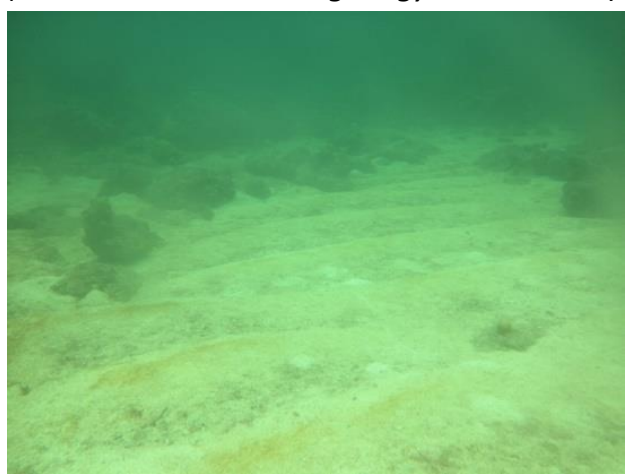

Gambar 8. Bentukan Dasar Pulau Nusa (Sumber: Balai Arkeologi Yogyakarta, 2017)

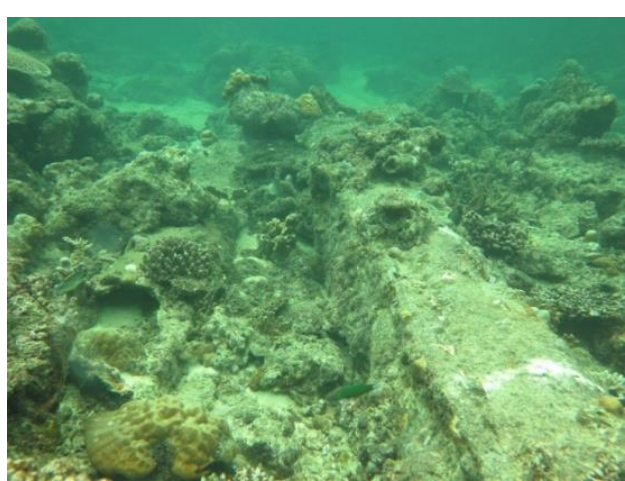

Gambar 10. Jenis Karang Acropora humilis (Sumber: Balai Arkeologi Yogyakarta, 2017)

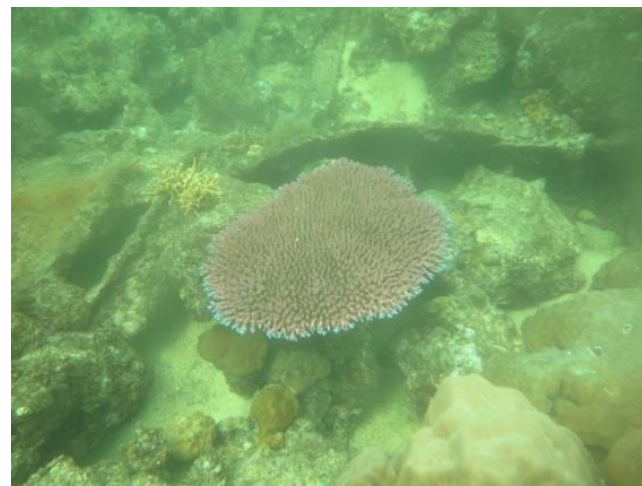

Gambar 12. Jenis Karang Acropora loripes (Sumber: Balai Arkeologi Yogyakarta, 2017)

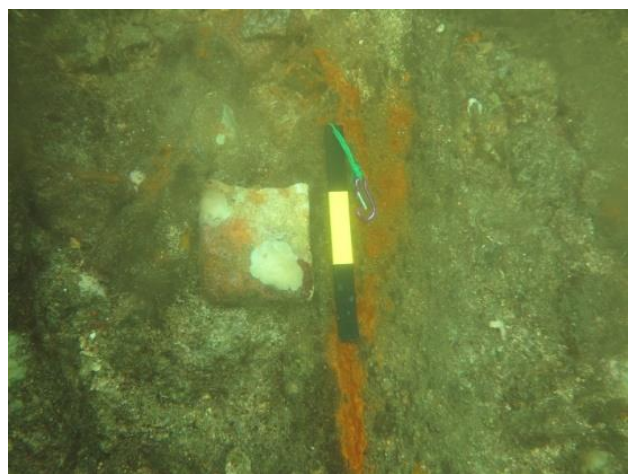

Gambar 7. Temuan Bata di Area Haluan (Sumber: Balai Arkeologi Yogyakarta, 2017)

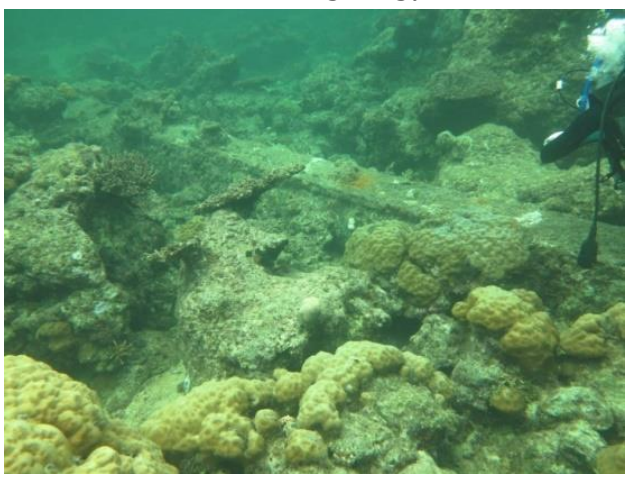

Gambar 9. Jenis Karang Porites sp., Acropora gemmifera dan Acropora humilis

(Sumber: Balai Arkeologi Yogyakarta, 2017)

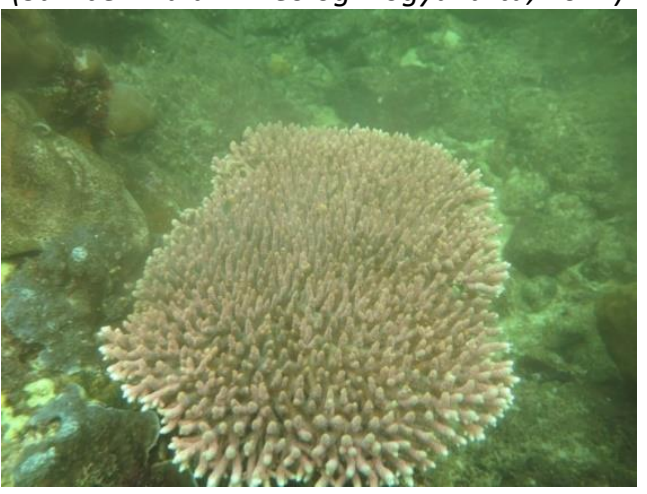

Gambar 11. Jenis Karang Acropora caroliniana

(Sumber: Balai Arkeologi Yogyakarta, 2017)

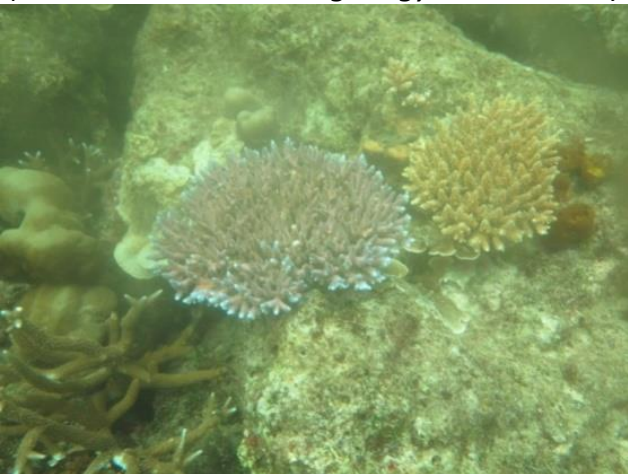

Gambar 13. Jenis Karang Acropora pulchra, Acropora granulosa dan Acropora gemmifera (Sumber: Balai Arkeologi Yogyakarta, 2017)

Berkala Arkeologi Vol.38 Edisi $\mathcal{N} 0.2$ November 2018 
Beberapa jenis karang yang terdapat di fragmen dan komponen shipwreck Pulau Nusa terdiri dari famili Poritidae dan Acroporidae seperti Porites sp., Acropora gemmifera, Acropora humilis, Acropora caroliniana, Acropora loripes, Acropora pulchra, Acropora granulosa, Acropora formosa, Acropora sarmentosa, Acropora millepora dan Acropora palifera yang tercantum pada Gambar 9-17.

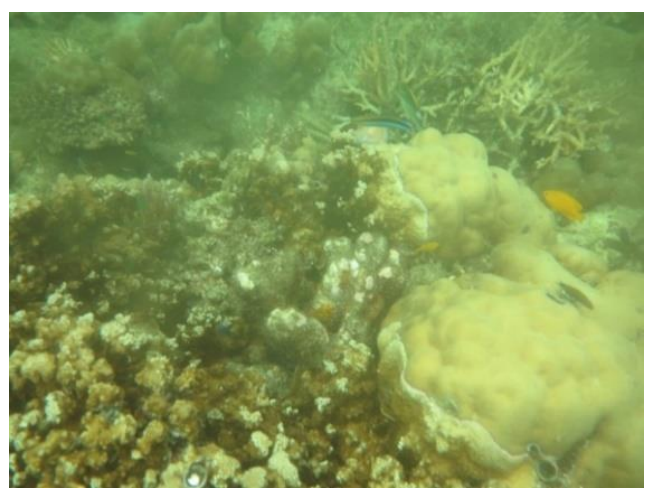

Gambar 14. Jenis Karang Acropora formosa (Sumber: Balai Arkeologi Yogyakarta, 2017)

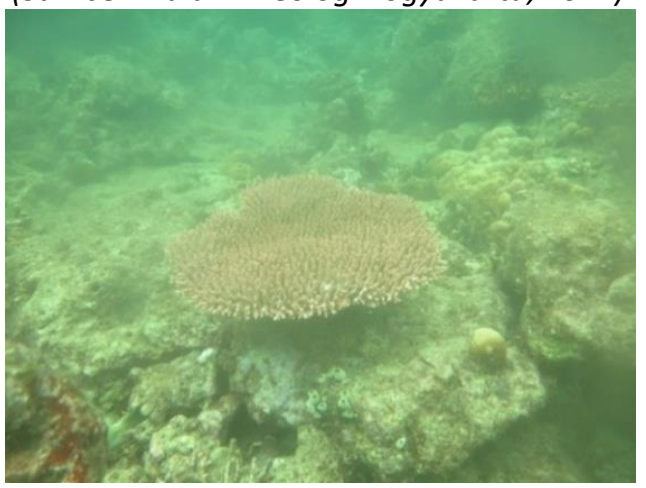

Gambar 16. Jenis Karang Acropora millepora (Sumber: Balai Arkeologi Yogyakarta, 2017)

Beberapa jenis ikan yang berada di sekitar shipwreck saat observasi berlangsung antara lain: ikan hias seperti ikan kepe-kepe layar kuning (Zanclus cornutus), ikan sersan mayor (Abudefduf vaigiensis), ikan gobi (Elacatinus evelynae), Damselfishes (Pomacentrus moluccensis), Parrotfishes, Surgeonfishes, ikan karang konsumsi seperti ikan kerapu (Epinephelus fusco- dguttatus) se-banyak delapan ekor, ikan kakap merah (Lutjanus campechanus) sebanyak dua ekor, dan tidak jauh dari lokasi shipwreck juga terlihat Cheilinus undulatus dan gerombolan ikan tongkol (Euthynnus affinis). Keberadaan jenis-jenis ikan tersebut juga didukung oleh banyaknya cekungan disekitar shipwreck yang dapat berfungsi sebagai rumah atau tempat singgah.

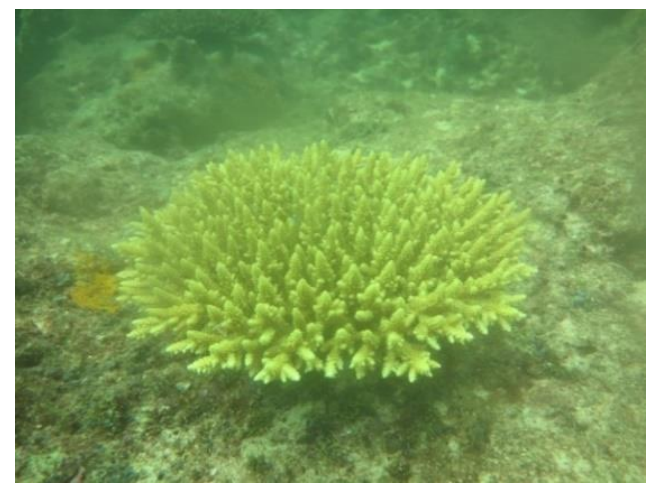

Gambar 15. Jenis Karang Acropora sarmentosa (Sumber: Balai Arkeologi Yogyakarta, 2017)

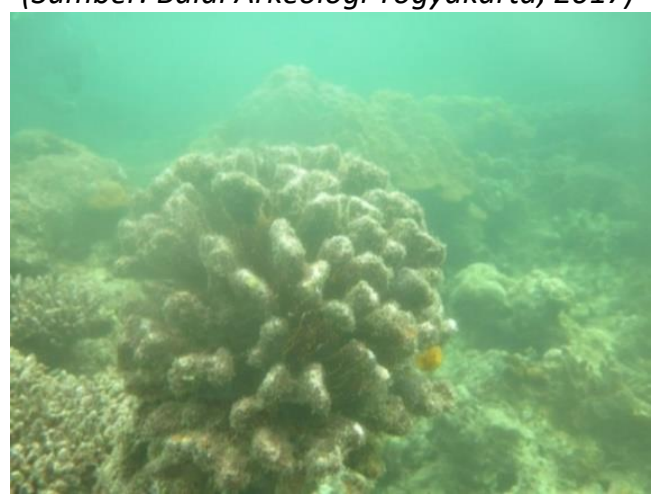

Gambar 17. Jenis Karang Acropora palifera (Sumber: Balai Arkeologi Yogyakarta, 2017)

\section{Kondisi Exposed Shipwreck dan Jenis Karang di Gosong Gili \\ Exposed shipwreck di}

Gosong Gili berada di kedalaman 3-5 meter dibagian reef flat dengan kondisi juga bersandar diantara gosong karang. Berdasarkan hasil observasi dan hasil penelitian Priswanto (2016) dan Taufiq (2017), exposed shipwreck tersebut juga berjenis kapal uap yang telah 
terpetakan dalam Ducth Colonial Maps tahun 1911 di Leiden University. Pendugaan exposed shipwreck di Gosong Gili sebagai SS Bengal mengacu pada karakter roda penggerak mesin uap dan beberapa boiler yang ditemukan (Priswanto, 2016: 75). Kapal SS Bengal memiliki dimensi ukuran $94,49 \times 11,95 \times 7,74$ meter dengan kapasitas 2103 GT dan tenggelam pada saat perjalanan

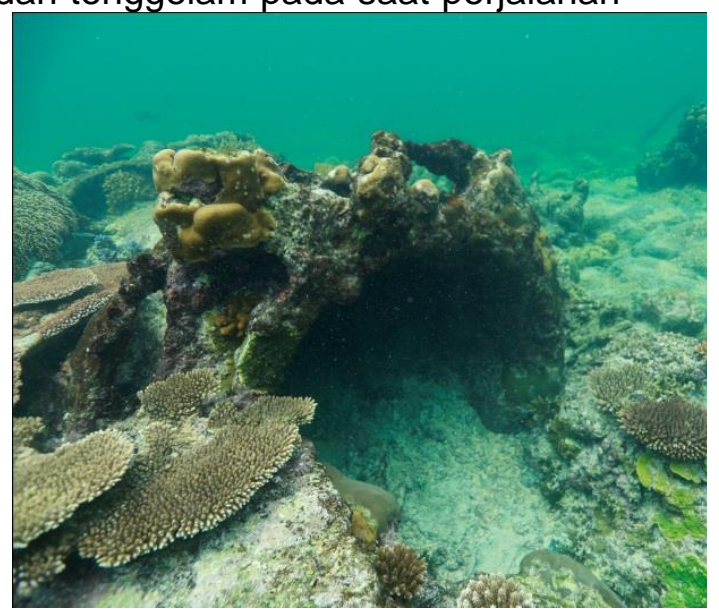

Gambar 18. Fragmen Boiler SS Bengal (Sumber: Guslan-Jawa Pos, 2017)

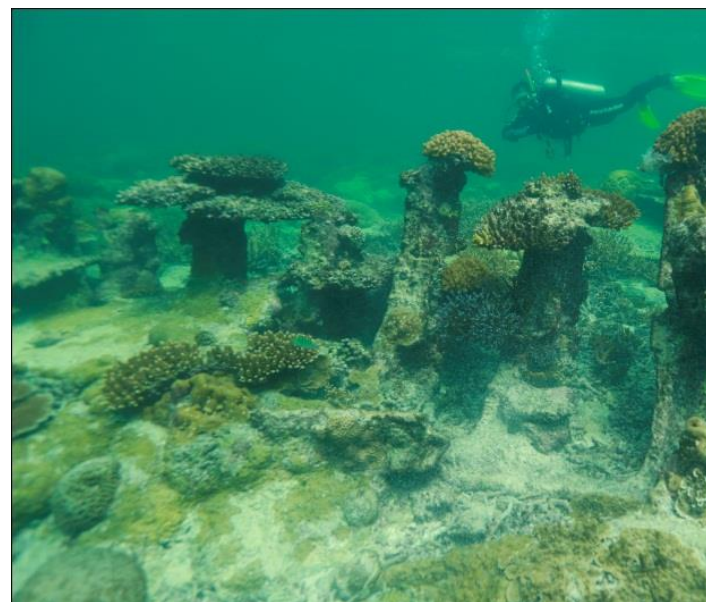

Gambar 20. Fragmen Gading-Gading SS Bengal (Sumber: Guslan-Jawa Pos, 2017) dari Saigon, Vietnam menuju ke Jawa, Indonesia dengan muatan berupa penumpang dan beras (Hocking, 1969: 79 dan Priswanto, 2016: 75). Kondisi exposed shipwreck di Gosong Gili cenderung lebih memprihatikan dikarenakan hanya tersisa $20 \%$ berupa fragmen boiler, komponen mesin dan fragmen gading-gading kapal. (Gambar 1820).

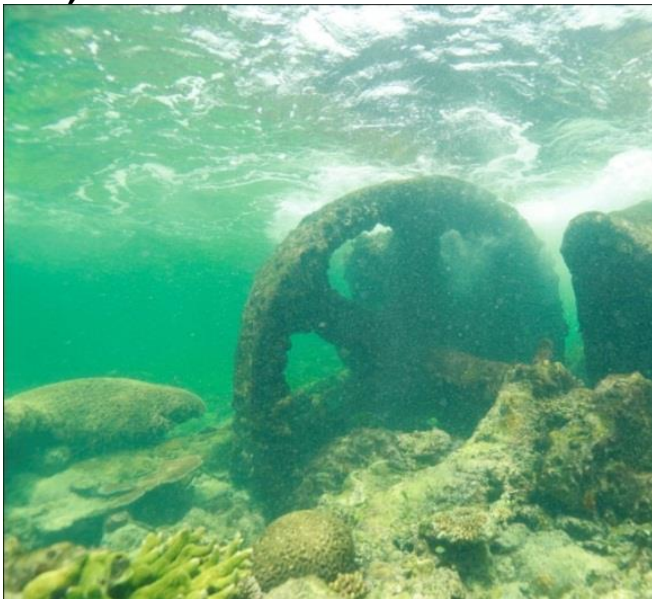

Gambar 19. Komponen Mesin SS Bengal (Sumber: Guslan-Jawa Pos, 2017)

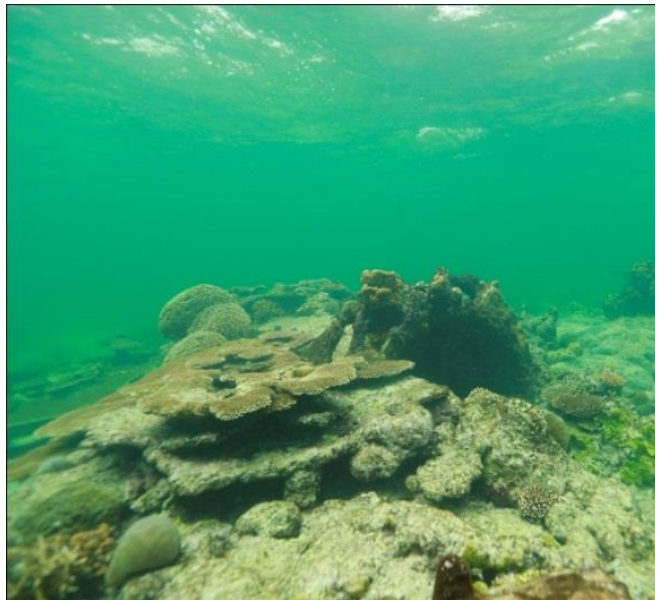

Gambar 21. Bentukan Dasar Perairan Gosong Gili

(Sumber: Guslan-Jawa Pos, 2017) 


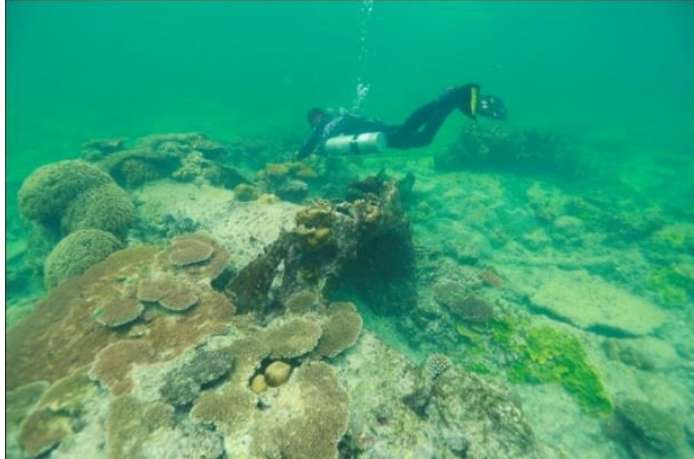

Gambar 22. Jenis Karang Acropora hyacinthus, Acropora humilis, Hydnophora microconos dan Goniopora tenuidens

(Sumber: Guslan-Jawa Pos, 2017)

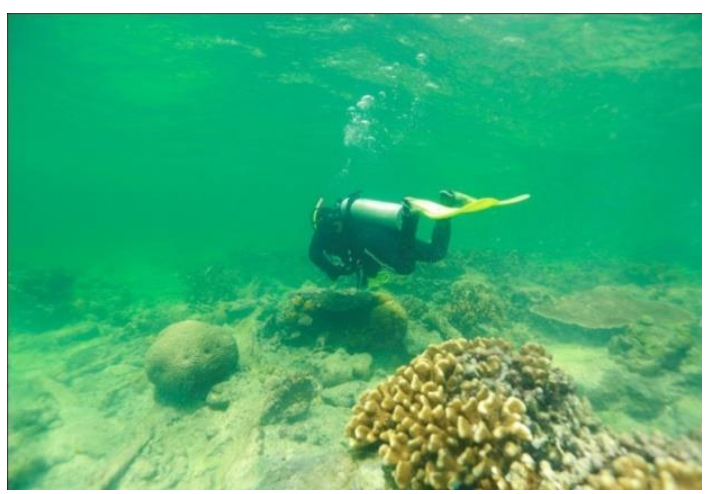

Gambar 24. Jenis Karang Platygyra sinensis, Porites lutea, Acropora palifera dan Acropora hyacinthus

(Sumber: Guslan-Jawa Pos, 2017)

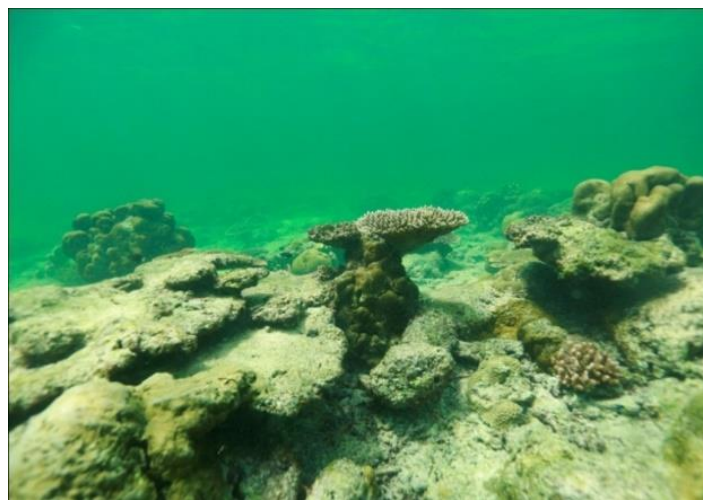

Gambar 26. Jenis Karang Acropora tenuis dan Acropora palifera

(Sumber: Guslan-Jawa Pos, 2017)

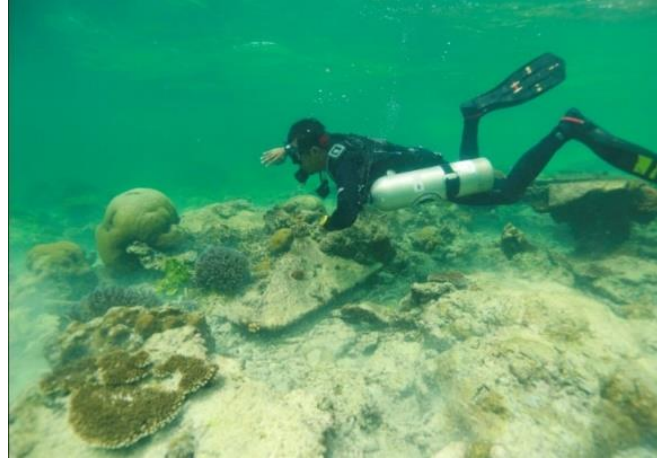

Gambar 23. Jenis Karang Porites lutea, Acropora humilis dan Acropora hyacinthus (Sumber: Guslan-Jawa Pos, 2017)

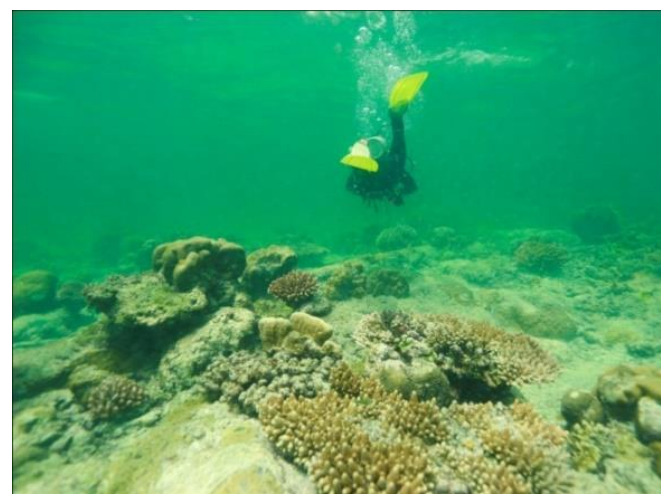

Gambar 25. Jenis Karang Platygyra sinensis dan Acropora gemmifera

(Sumber: Guslan-Jawa Pos, 2017)

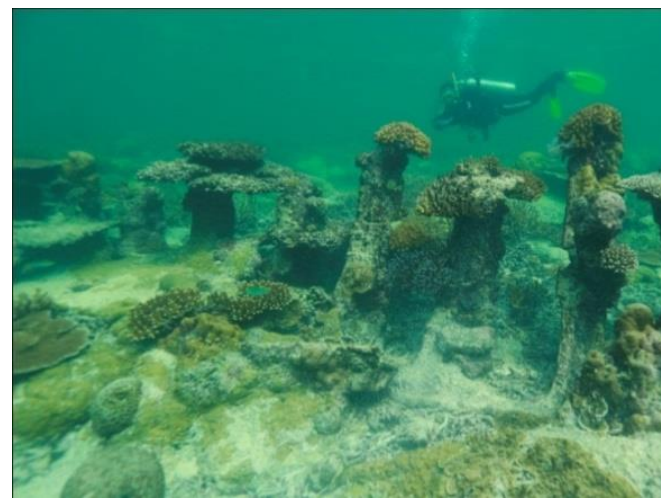

Gambar 27. Jenis Karang Acropora intermedia, Acropora samoensis dan Acropora hyacinthus

(Sumber: Guslan-Jawa Pos, 2017) 


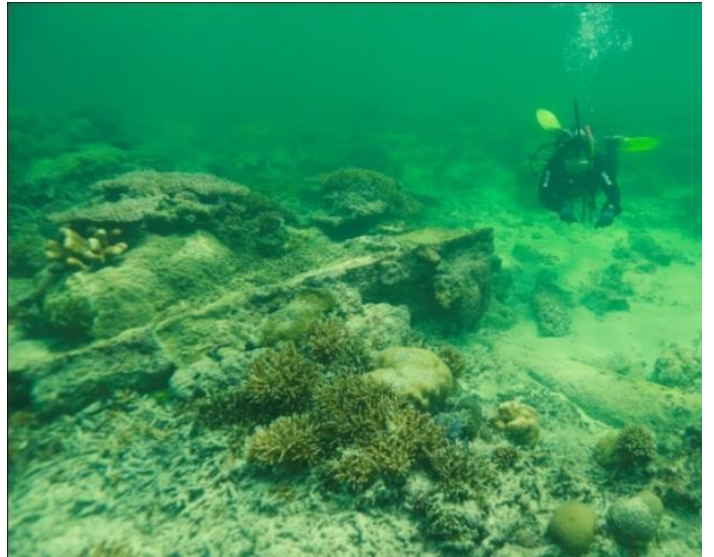

Gambar 28. Jenis Karang Acropora palifera dan Acropora aspera

(Sumber: Guslan-Jawa Pos, 2017)

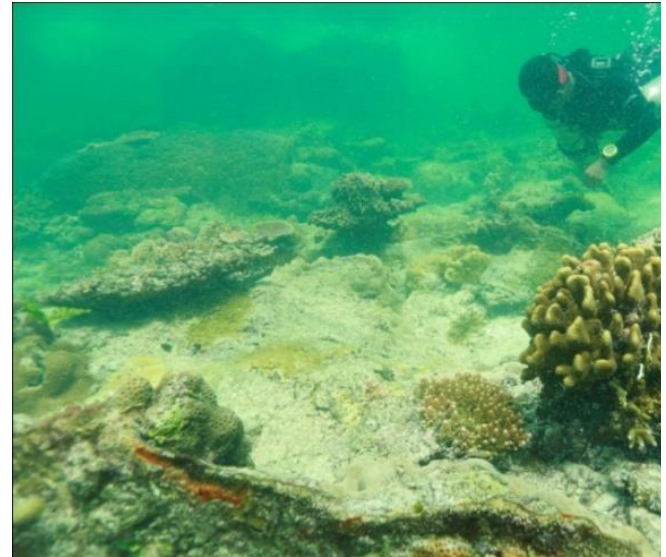

Gambar 29. Jenis Karang Acropora palifera dan Acropora gemmifera

(Sumber: Guslan-Jawa Pos, 2017)

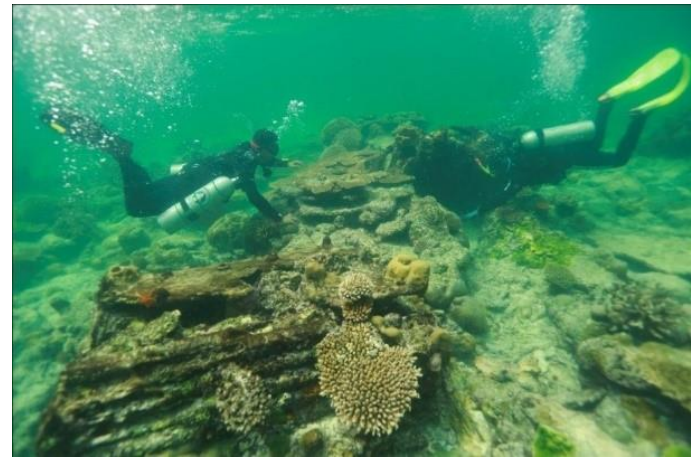

Gambar 30. Jenis Karang Acropora tenuis, Acropora palifera dan Acropora hyacinthus (Sumber: Guslan-Jawa Pos, 2017)

Exposed shipwreck di Gosong Gili juga telah ditumbuhi oleh berbagai jenis karang. Pertumbuhan karang juga didukung dengan material sedimen dasar perairan berupa pasir dan memiliki tingkat kejernihan mencapai lebih dari 5 meter. Topografi perairan Gosong Gili cenderung lebih terbuka tanpa adanya penghalang atau pelindung seperti keberadaan pulau atau gosong pasir, sehingga kondisi hidrooseanografi bersifat lebih dinamis. Lokasi tersebut juga dihindari oleh nelayan sekitar karena memiliki mitos dapat menyesatkan navigasi kapal dan mengkandaskan kapal (Priswanto, 2015: 15). Jenis karang yang tumbuh disekitar exposed shipwreck Gosong
Gili cenderung lebih banyak bila dibandingkan dengan Pulau Nusa, antara lain: Acropora hyacinthus, Acropora humilis, Hydnophora microconos, Goniopora tenuidens, Porites lutea, Platygyra sinensis, Acropora palifera, Acropora gemmifera, Acropora tenuis, Acropora intermedia, Acropora samoensis dan Acropora aspera (Gambar 21-30). Pada saat obervasi, jenis ikan yang ditemui disekitar exposed shipwreck Gosong Gili cenderung lebih sedikit dibanding dengan Pulau Nusa, antara lain: Longfin Damselfish, ikan sersan mayor (Abudefduf vaigiensis), ikan gobi (Elacatinus evelynae) dan Surgeonfishes. Kondisi ini berkaitan dengan arus perairan Gosong Gili 
yang cenderung mengalami swing sehingga tidak banyak ikan yang melintas di sekitar exposed shipwreck.

Karang disekitar shipwreck Pulau Nusa maupun exposed shipwreck Gosong Gili dapat membentuk ekosistem terumbu karang yang memungkinkan kehadiran berbagai jenis biota laut untuk tinggal atau transit. Kualitas pertumbuhan karang tersebut juga sangat dipengaruhi oleh kualitas lingkungan perairan terutama faktor hidrooseanografi dan keberadaan polutan seperti potasium.

\section{DISKUSI DAN PEMBAHASAN}

Beberapa peristiwa kapal tenggelam di perairan Pulau Bawean terutama di Pulau Nusa dan Gosong Gili tidak terlepas dari faktor kondisi hidrooseanografi yang cukup dinamis, tingkat kerapatan karang cukup tinggi dan adanya kesalahan navigasi saat kapal sedang berlayar. Hal ini dibuktikan dengan lokasi penemuan shipwreck maupun exposed shipwreck yang bersandar di gosong karang dengan kedalaman perairan berkisar 3-7 meter.

Berdasarkan konstruksi kapal yang diketahui dari temuan fragmen dan komponen yang tersisa, temuan muatan kapal berupa bata dan nilai historis yang terkandung pada kedua jenis kapal uap tersebut, maka shipwreck di Pulau Nusa dan exposed shipwreck di Gosong Gili memiliki potensi sebagai cagar budaya sehingga diperlukan upaya perlindungan dan pelestarian terlebih bila melihat bagian-bagian shipwreck atau exposed shipwreck yang masih tersisa di kedua lokasi. Hal ini sesuai dengan kriteria cagar budaya yang terdapat pada Pasal 5 UndangUndang Nomor 11 Tahun 2010 tentang Cagar Budaya, antara lain: berusia 50 tahun atau lebih, mewakili masa gaya paling singkat berusia 50 (lima puluh) tahun; memiliki arti khusus bagi sejarah, ilmu pengetahuan, pendidikan, agama, dan/atau kebudayaan; dan memiliki nilai budaya bagi penguatan kepribadian bangsa. Kondisi shipwreck di Pulau Nusa dan exposed shipwreck di Gosong Gili yang memprihatikan disebabkan adanya aktivitas perburuan dan pencurian besi tua dalam kurun waktu cukup lama yang dilatarbelakangi oleh nilai jual besi tua cukup tinggi baik dipasar domestik maupun internasional. Hal ini menunjukkan masih rendahnya tingkat kesadaran dan kepedulian masyarakat terhadap shipwreck atau exposed shipwreck yang memiliki nilai historis sebagai cagar budaya dan nilai ekologis sebagai media tumbuhnya berbagai jenis karang, sehingga diperlukan upaya perlindungan, pengembangan dan pemanfaatan shipwreck atau exposed shipwreck yang melibatkan seluruh pihak terkait untuk melestarikan dan meningkatkan nilai fungsi shipwreck atau exposed shipwreck.

Upaya tersebut dapat direalisasikan dengan pengembangan shipwreck atau exposed shipwreck menjadi museum bawah air secara in situ sebagai sarana edukasi bagi masyarakat untuk mempelajari nilai historis dan budaya masa lampau yang terkandung dalam shipwreck atau exposed shipwreck. Penetapan shipwreck atau exposed shipwreck menjadi museum bawah air secara in situ didasarkan pada Convention on the Protection of the Underwater Cultural Heritage oleh (UNESCO, 2001b: 11), yang mendefinisikan warisan budaya bawah air sebagai keseluruhan jejak eksistensi manusia yang memiliki

Peranan Ekologis Shipwreck atau Exposed Shipwreck Sebagai Media Hidup

Karang di Pulau Bawean dalam Upaya Perlindungan, Pengembangan dan Pemanfaatan

Shipwreck atau Fxposed Shipwreck

(Heny Budi Setyorini, Heri Priswanto, Ahmad Surya Ramadhan) 
nilai budaya, sejarah ataupun karakter arkeologi dimana baik sebagian atau keseluruhan bagian tersebut berada di bawah air yang secara berkala atau terus menerus telah berusia minimal 100 tahun. Selain itu, penetapan tersebut juga didasarkan pada nilai historis yang terkandung dalam shipwreck di Pulau Nusa dan exposed shipwreck di Gosong Gili antara lain: konstruksi kapal, muatan kapal dan tujuan pelayaran kapal sebagaimana yang telah disampaikan oleh Hocking (1969); Priswanto (2015); Priswanto (2016) dan Taufiq (2017). Beberapa contoh penetapan shipwreck atau exposed shipwreck menjadi museum bawah air secara in situ dan lokasi penyelaman antara lain: Yongala shipwreck yang telah ditetapkan menjadi lokasi penyelaman nomor 1 diseluruh dunia pada tahun 2006 oleh website www.scubatravel.com, sedangkan Thistlegorm wreck di Laut Merah dan Liberty wreck di Bali yang ditetapkan menjadi lokasi penyelaman nomor 9 (UNESCO, 2001a: 20) dan Kawasan Konservasi Maritim HMAS Perth di Perairan Provinsi Banten (Keputusan Menteri Kelautan dan Perikanan, 2018).

Shipwreck atau exposed shipwreck juga dapat dikembangkan menjadi lokasi penanaman terumbu karang buatan yang sekaligus menjadi upaya rehabilitasi ekosistem terumbu karang di Pulau Bawean. Berdasarkan observasi di lapangan, kerusakan ekosistem terumbu karang di Pulau Bawean disebabkan oleh teknik penangkapan ikan menggunakan potasium yang dibuktikan dengan bentuk dan warna pecahan karang yang cenderung berwarna gelap dan keputihan dibagian ujung karang. Kondisi tersebut juga berdampak pada hilangnya berbagai jenis biota perairan penghuni ekosistem terumbu karang dan lokasi fishing ground bagi nelayan juga semakin jauh sehingga pendapatan nelayan berkurang. Hal ini didukung dengan hasil penelitian Hoffmann (2002: 1291), bahwa kesehatan terumbu karang dipengaruhi oleh aktivitas manusia seperti industri dan penggunaan lahan, yang berkelanjutan dapat berdampak pada tingkat perekonomian masyarakat di Pulau Cook dan Fiji.

Pengembangan shipwreck atau exposed shipwreck menjadi lokasi penanaman terumbu karang buatan juga didasarkan pada peranan ekologis shipwreck atau exposed shipwreck sebagai media hidup karang dan keanekaragaman karang yang hidup disekitar shipwreck di Pulau Nusa maupun exposed shipwreck di Gosong Gili. Pertumbuhan karang disekitar shipwreck atau exposed shipwreck umumnya diawali dengan proses korosi pada seluruh bagian kapal yang berbahan besi kemudian diikuti dengan tumbuhnya lumut yang menyelimuti besi tersebut hingga adanya karang yang menempel pada salah satu sisi besi dan membentuk terumbu karang. Sebagaimana hasil penelitian (MacLeod, Selman, dan Selman, 2017: 111), bahwa bangkai kapal besi yang tenggelam di Chuuk Lagoon telah mengalami korosi, dimana proses korosi menurun secara linier seiring dengan peningkatan kedalaman hingga 32 $\mathrm{m}$. Selanjutnya hasil penelitian (Schroeder, dkk, 2008: 351), juga menunjukkan bahwa pada tahun 1995, populasi surgeonfishes jenis herbivora telah menghuni dan mendominasi shipwreck di Rose Atoll yang diakibatkan ketertarikan ikan tersebut terhadap blooming alga. Penelitian tersebut juga mengungkapkan bahwa pada tahun 2002-2006 jumlah dan biomassa 
ikan-ikan herbivora meningkat siginifikan di lokasi shipwreck bila dibandingkan di lokasi reef-slope yang lain karena bagian puing-puing baja yang berkarat telah ditutupi oleh ganggang oportunistik (rumput dan cyanobacteria) (Schroeder dkk., 2008: 356).

Pertumbuhan karang yang cukup baik terutama disekitar exposed shipwreck di Gosong Gili juga didukung oleh tingkat kejernihan perairan dan material sedimen dasar perairan. Beberapa penelitian juga telah melaporkan keterkaitan faktor lingkungan dengan kelangsungan hidup karang antara lain: Yentsch, dkk (2002), Siringoringo (2007), Alamaru, dkk (2009), Harborne, dkk (2011), Ben-Zvi, Eyal, dan Loya (2015) dan Bessell-Browne, dkk (2017).

Pembentukan terumbu karang pada shipwreck atau exposed shipwreck secara berkelanjutan dapat menjadi faktor penarik bagi organisme yang berasosiasi dengan karang untuk sekedar transit ataupun tinggal menetap dilokasi tersebut sehingga secara alami akan terbentuk ekosistem terumbu karang. Hal ini dikarenakan pada lokasi shipwreck atau exposed shipwreck tersedia suplai pakan alami dari fitoplankton dan mikroalga yang berasosiasi dengan karang sehingga dapat dijadikan sebagai tempat untuk mencari makan (feeding ground) ataupun tempat asuhan (nursery ground) bagi biota penghuni ekosistem terumbu karang seperti berbagai jenis ikan hias maupun ikan karang konsumsi (Emmanuel dan Onyema, 2007; Chaves, Pereira, dan Feitosa, 2013). Selain itu, shipwreck atau exposed shipwreck juga seringkali menjadi tempat transit bagi organisme peruaya seperti ikan tongkol (Euthynnus affinis) yang muncul di sekitar shipwreck Pulau Nusa.

Beberapa penelitian juga telah melaporkan keberadaan organisme asosiasi ekosistem terumbu karang di sekitar shipwreck atau exposed shipwreck. Hasil penelitian dari Oakley (1988: 77), menunjukkan adanya populasi karang hitam Antipathes pennacea (Pallas) disekitar shipwreck yang telah tenggelam selama 37 tahun di Perairan Jamaika. Selanjutnya hasil penelitian Work, Aeby, dan Maragos (2008: 1), juga menunjukkan bahwa terdapat pergeseran fasa dari karang ke corallimorpharian Rhodactis howesii yang berasosiasi dengan long line vessel wreck yang tenggelam pada tahun 1991 di bagian atol Palmyra (bagian tengah) Samudra Pasifik. Begitu pula dengan hasil penelitian Hadi, Hartati dan Widianingsih (2011: 239), yang dilakukan pada tahun 2005 juga telah menunjukkan keberadaan Echinodermata sebanyak 12 spesies dari 4 kelas, yaitu Asteroidea, Crinoidea, Echinoidea dan Holothuroidea, sedangkan pada tahun 2006 hasil penelitian menunjukkan 13 spesies dari 4 kelas, yaitu Asteroidea, Crinoidea, Echinoidea dan Holothuroidea yang terdapat disekitar bangkai kapal Indonoor yang tenggelam di bagian tubir Pulau Kemujan, Kepulauan Karimunjawa pada tahun 1960.

Kondisi inilah yang mendasari pengembangan shipwreck atau exposed shipwreck menjadi lokasi pengembangan ekowisata bahari, selain wisatawan dapat mempelajari tentang nilai historis shipwreck atau exposed shipwreck juga dapat berinteraksi secara langsung dengan ekosistem terumbu karang. Pengembangan ekowisata bahari juga dapat berintegrasi dengan lokasi yang lain di Pulau Bawean seperti Gili Noko

Peranan Ekologis Shipwreck atau Exposed Shipwreck Sebagai Media Hidup

Karang di Pulau Bawean dalam Upaya Perlindungan, Pengembangan dan Pemanfaatan

Shipwreck atau Fxposed Shipwreck

(Heny Budi Setyorini, Heri Priswanto, Ahmad Surya Ramadhan) 
untuk menarik kedatangan wisatawan. Berdasarkan penjelasan di atas, maka sudah sepatutnya shipwreck di Pulau Nusa dan exposed shipwreck di Gosong Gili mendapat upaya perlindungan untuk melestarikan nilai historis, ekologis dan ekonomis yang terkandung di dalamnya dengan meningkatkan peran serta seluruh pihak terkait baik dari instansi pemerintah hingga masyarakat setempat.

\section{KESIMPULAN}

Kondisi shipwreck di Pulau Nusa hanya bersisa $30 \%$ berupa fragmen tiang kapal, fragmen mesin kapal, komponen boiler kapal, fragmen baling-baling (propeller), fragmen gading-gading dan temuan bata di area haluan, sedangkan exposed shipwreck di Gosong Gili hanya bersisa $20 \%$ berupa fragmen boiler, komponen mesin dan fragmen gading-gading kapal yang berpotensi sebagai cagar budaya menurut Undang-Undang Nomor 11 Tahun 2010 tentang Cagar Budaya. Beberapa jenis karang yang terdapat di Pulau Nusa terdiri dari famili Poritidae dan Acroporidae dan ditemukan berbagai jenis ikan hias karang dan ikan konsumsi, sedangkan jenis karang yang terdapat di perairan Gosong Gili terdiri dari famili Merulinidae, Poritidae dan Acroporidae dan ditemukan berbagai jenis ikan hias karang yang lebih sedikit dibanding Pulau Nusa.

\section{SARAN/REKOMENDASI}

Shipwreck di Pulau Nusa dan exposed shipwreck Gosong Gili memiliki potensi sebagai cagar budaya dan peranan ekologis sebagai media hidup karang dan rumah ikan karang, sehingga diperlukan upaya perlindungan, pengembangan dan pemanfaatan melalui penetapan shipwreck atau exposed shipwreck menjadi museum bawah air secara in situ dengan meningkatkan peran serta seluruh pihak terkait baik dari instansi pemerintah hingga masyarakat setempat. Sebagai upaya pengembangan dan pemanfaatan shipwreck atau exposed shipwreck menjadi lokasi penanaman terumbu karang buatan dan ekowisata bahari, maka diperlukan kajian tentang struktur komunitas karang yang berada disekitar shipwreck atau exposed shipwreck sebagai pertimbangan upaya rehabilitasi ekosistem terumbu karang, kajian tentang hidrooseanografi perairan Pulau Bawean terutama Gosong Gili untuk mempertimbangkan keamanan penyelaman serta kajian tentang potensi dan strategi pengembangan ekowisata bahari Pulau Bawean secara keseluruhan.

\section{UCAPAN TERIMA KASIH}

Penulis mengucapkan terima kasih kepada Balai Arkeologi Daerah Istimewa Yogyakarta atas kesempatan yang diberikan untuk mengikuti rangkaian penelitian di Pulau Bawean. Ucapan terima kasih juga penulis sampaikan kepada civitas akademika Institut Teknologi Yogyakarta yang telah memberikan ijin untuk mengikuti kegiatan tersebut. Penulis juga mengucapkan terima kasih kepada tim Sentra Selam Jogja yang telah membantu dalam pengambilan data kondisi shipwreck atau exposed shipwreck, jenis karang dan ikan atau biota perairan di sekitar shipwreck atau exposed shipwreck. 


\section{DAFTAR PUSTAKA}

Abdullah, Roksana Bibi Bte. 2006. "Pengalihan Bahasa Di Kalangan Masyarakat Bawean Di Singapura: Sebab Dan Akibat." Singapore. https://repository.nie.edu.sg/bitstream/10497/15651/1/PABSB-2006285_a.pdf.

Alamaru, Ada, Yossi Loya, Eran Brokovich, Ruth Yam, and Aldo Shemesh. 2009. "Carbon and Nitrogen Utilization in Two Species of Red Sea Corals along a Depth Gradient: Insights from Stable Isotope Analysis of Total Organic Material and Lipids." Geochimica et Cosmochimica Acta 73 (18):5333-42. https://doi.org/10.1016/j.gca.2009.06.018.

Allen, Gerald, Roger Steene, Paul Humann, and Ned DeLoach. 2005. Reef Fish Identification Tropical Pacific. Florida: New World Publications.

Ardiwidjaja, Roby. 2017. "Pelestarian Tinggalan Budaya Bawah Air: Pemanfaatan Kapal Karam Sebagai Daya Tarik Wisata Selam." Jurnal Penelitian Dan Pengembangan Arkeologi 35 (2):75-148.

Ben-Zvi, Or, Gal Eyal, and Yossi Loya. 2015. "Light-Dependent Fluorescence in the Coral Galaxea Fascicularis." Hydrobiologia 759 (1):15-26. https://doi.org/10.1007/s10750-014-2063-6.

Bessell-Browne, Pia, Andrew P. Negri, Rebecca Fisher, Peta L. Clode, Alan Duckworth, and Ross Jones. 2017. "Impacts of Turbidity on Corals: The Relative Importance of Light Limitation and Suspended Sediments." Marine Pollution Bulletin $117 \quad(1-2)$. Elsevier Ltd:161-70. https://doi.org/10.1016/j.marpolbul.2017.01.050.

Chaves, L. T.C., P. H.C. Pereira, and J. L.L. Feitosa. 2013. "Coral Reef Fish Association with Macroalgal Beds on a Tropical Reef System in North-Eastern Brazil." Marine and Freshwater Research 64 (12):1101-11. https://doi.org/10.1071/MF13054.

Commodore Commanding China Force. 1948. "Battle of The Java Sea, 27th February, 1942." H.M. Stationery Office, July 1948.

Cribb, Robert, and Michele Ford. 2009. Indonesia Beyond the Water's Edge Managing an Archipelagic State. Singapore: Institute of Southeast Asian Studies.

Denlay, Kevin. 2010. “Summary of Expedition 'Operation Dukedom' - Explorers Club Flag \#52." Malacca Strait.

Dillenia, Ira, and Luh Putu Ayu Savitri Chitra Kusuma. 2009. "Sumberdaya Arkeologi Laut Untuk Pengembangan Ekowisata Bahari Di Indonesia: Tinjauan Konsep Dan Studi Kasus." In Pertemuan IImiah Tahunan VI ISOI 2009, edited by Bisman Nababan, 423-34. Bogor: Ikatan Sarjana Oseanologi Indonesia (ISOI). 
Edy, Catur Waskito. 2016. "Belanda Protes, Bangkai Kapal Perangnya Yang Tenggelam Di Laut Jawa Hilang 'Dikiloin' Warga," 2016. http://jateng.tribunnews.com/2016/11/18/belanda-protes-bangkai-kapalperangnya-yang-tenggelam-di-laut-jawa-hilang-dikiloin-warga?page $=2$.

Emmanuel, B E, and I C Onyema. 2007. "The Plankton and Fishes of a Tropical Creek in South-Western Nigeria." Turkish Journal of Fisheries and Aquatic Sciences 113:105-13.

Hadi, Abdul, and Retno Hartati. 2011. "Fauna Echinodermata Di Indonoor Wreck, Pulau Kemujan , Kepulauan Karimunjawa” 16 (4):236-42.

Harborne, Alastair R., Peter J. Mumby, Emma V. Kennedy, and Renata Ferrari. 2011. "Biotic and Multi-Scale Abiotic Controls of Habitat Quality: Their Effect on Coral-Reef Fishes." Marine Ecology Progress Series 437:201-14. https://doi.org/10.3354/meps09280.

Harmar, T. 2010. "Part of the Island Lubeck, Called by the Natives Babean." Bibliotheque Nationale de 2010. http://gallica.bnf.fr/ark:/12148/btv1b5963377t.r=bawean.langEN.

Hocking, Charles. 1969. Dictionary of Disasters at Sea During the Age of Steam: Including Sailing Ships and Ships of War Lost in Action, 1824-1962. London: Lloyd's Register.

Hoffmann, Tegan. 2002. "Coral Reef Health and Effects of Socio-Economic Factors in Fiji and Cook Islands." Marine Pollution Bulletin 44:1281-93. https://doi.org/10.1016/S0025-326X(02)00260-6.

Keputusan Menteri Kelautan dan Perikanan. 2018. Keputusan Menteri Kelautan Dan Perikanan Republik Indonesia Nomor 21/KepMen-KP/2018.

MacLeod, Ian D., Allison Selman, and Chris Selman. 2017. "Assessing the Impact of Typhoons on Historic Iron Shipwrecks in Chuuk Lagoon Through Changes in the Corrosion Microenvironment." Conservation and Management of Archaeological Sites 19 (4):269-87.

Müller, Kal, and David Pickell. 1999. Diving Indonesia: A Guide to World's Greatest Diving Diving Indonesia: A Guide to the World's Greatest Diving (Periplus Action Guides). Hong Kong: Periplus Editions.

Oakley, S. G. 1988. "Settlement and Growth of Antipathes Pennacea on a Shipwreck." Coral Reefs 7 (2):77-79. https://doi.org/10.1007/BF00301644.

Priswanto, Hery. 2015. "Bentuk Dan Karakter Tinggalan Arkeologi Maritim Di Pulau Bawean: Identifikasi Potensi (Tahap I).” Daerah Istimewa Yogyakarta.

. 2016. "Bentuk Dan Karakter Tinggalan Arkeologi Maritim Di Pulau Bawean: Identifikasi Potensi (Tahap II)." Daerah Istimewa Yogyakarta. 
Salazar, Noel B. 2016. "The (Im) Mobility of Merantau as a Sociocultural Practice in Indonesia." https://lirias.kuleuven.be/bitstream/123456789/559306/1/Gregoric_01_Salaz ar.pdf.

Schroeder, Robert E, Alison L Green, Edward E DeMartini, and Jean C Kenyon. 2008. "Long-Term Effects of a Ship-Grounding on Coral Reef Fish Assemblages at Rose Atoll, Amreican Samoa." Bulletin of Marine Science 82 (3):345-64.

Siberg, J.A. 2015. "Een Pasangrahan in de Dessa Kepoh Op Het Eiland Bawean." 2015. http://collectie.tropenmuseum.nl/Default.aspx.

Siringoringo, Rikoh Manogar. 2007. "Pemutihan Karang Dan Beberapa Penyakit Karang." Oseana XXXII (4):29-37.

Suharsono. 2008. Jenis-Jenis Karang Di Indonesia. Jakarta: LIPI Press.

Taufiq, Muhammad. 2017. "Tinggalan Kapal Uap Di Perairan Pulau Bawean: Bentuk, Fungsi Dan Peranannya Dalam Aktivitas Pelayaran Di Masa Lalu." Universitas Gadjah Mada, Yogyakarta.

UNESCO. 2001a. "The Benefit of the Protection of Underwater Cultural Heritage for Sustainable Growth, Tourism and Urban Development." France.

- 2001b. "The UNESCO Convention on the the Protection of the Underwater Cultural Heritage." France.

Work, Thierry M., Greta S. Aeby, and James E. Maragos. 2008. "Phase Shift from a Coral to a Corallimorph-Dominated Reef Associated with a Shipwreck on Palmyra Atoll." PLoS ONE 3 (8):1-5. https://doi.org/10.1371/journal.pone.0002989.

Yentsch, C. S., C. M. Yentsch, J. J. Cullen, B. Lapointe, D. A. Phinney, and S. W. Yentsch. 2002. "Sunlight and Water Transparency: Cornerstones in Coral Research." Journal of Experimental Marine Biology and Ecology 268 (2):17183. https://doi.org/10.1016/S0022-0981(01)00379-3. 
